\title{
Waar is die gereformeerde lidmate dan?
}

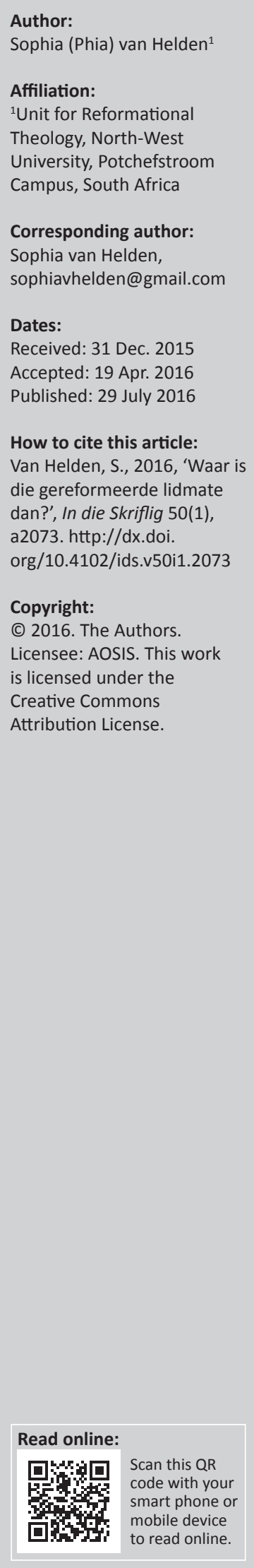

This article discusses the numbers of church members within the reformed main stream churches as researched during the past decade, while focusing on the disappearance process of white members as researched within sample congregations of the RCSA, as well as the absence of growing numbers among black congregations amid the huge South African population growth. To identify trends, the most recent available information regarding the activity of evangelising in congregations, the terminating of membership and whether members leave or arrive with of without testimony, were researched. Reasons are given why numbers increased in a few congregations. These congregations are thus not part of the declining trend in the traditional white congregations, and also not part of the not-growing, stagnated traditional black RCSA-congregations. The literature study, as well as the qualitative and quantitative approach, provides useful information and valuable insights in the recent tendencies regarding the eccleciastical survival battle.

\section{Inleiding}

Vanaf 2005 tot 2009 is navorsing in verband met die oorsake van kerkkrimping en dalende getalle binne die susterskerke gedoen. Die empiriese studie wat tydens die navorsingsperiode gedoen is, het egter net die Gereformeerde Kerke in Suid-Afrika (GKSA) betrek. Na 10 jaar is dit nodig om die tendens weer van nader te beskou. Dit word weereens deur 'n literatuurstudie gedoen asook empiriese navorsing aan die hand van 'n steekproef. Die steekproef wat in 2005-2009 gedoen is (vgl. Van Helden 2010:294-351), het slegs die klein GKSA-gemeentes binne twee provinsies betrek. Die navorsing wat in 2014-2015 gedoen is, sluit hierby aan. Die 2014-2015-navorsing is egter heelwat meer omvattend in die sin dat nie nét op die klein gemeentes gefokus is nie, maar dat al die GKSA-klassisse betrek is. Die navorsing is nog verder uitgebrei deurdat die swart gemeentes wat die afgelope 10 jaar tot die GKSA toegevoeg is, deel daarvan uitmaak. Ook elke swart gemeente wat nie vakant is nie, is betrek om moontlike tendense te identifiseer. Hierdie artikel poog om die soeke na ooreenkomste en eenheid te bevorder ten spyte van reuse kontekstuele verskille.

In elke klassis is drie verskillende groottes gemeentes as respondente vir die navorsing gebruik om sodoende landswyd moontlike tendense te probeer peil. Die gemeentes wat as respondente gedien het, was die grootste, die kleinste en 'n tussen-in gemeente binne elke klassis. 'n Tweede verskil tussen die navorsing van 2005-2009 en dié van 2014-2015 is dat die respondente nie dieselfde gemeentelede was as in die navorsing van 2005-2009 nie, maar wel die leraars van die gemeentes. Aspekte in verband met die laaste jaar van die afgelope dekade (tot en met 2015) word bespreek om die huidige stand binne gemeentes rakende die verdwynende lidmate, moontlike tendense en die beweging landswyd te peil.

Die Suid-Afrikaanse bevolking was teen die middel van 2015 ongeveer 54.96 miljoen (South Africa, Department of Statistics 2015), met die swart bevolking 80.5\% (44 228000 ) teenoor die wit en bruin bevolking wat onderskeidelik as $8.3 \%$ (4 534 000) en $8.8 \%$ (4 832 900) van die totale bevolking beloop het. Die navorsing oor die huidige Suid-Afrikaanse statistiek aangaande die bevolking behoort die GKSA daarvan bewus te maak om volhoubaar vir die baie groot uitdagings wat voorlê, gereed te maak.

Die literatuurstudie asook die kwalitatiewe en kwantitatiewe aanpak, bied interessante inligting waardeur die wit gemeentes aangemoedig word om te beplan ten einde die krimpende tendens tot 'n groeiende missionale tendens om te keer. Terselfdertyd word die swart gemeentes aangemoedig om te beplan ten einde die niegroeiende gemeentes tot 'n missionale bediening te wysig te midde van die toenemende duisendes wat die evangelie nog nie gehoor het nie. 


\section{Krimpende en niegroeiende gemeentes}

Volgens Oosthuizen (2014) het die NG Kerk in een jaar (2014) meer as 35000 lidmate verloor. Dit is heelwat meer as ooit tevore in hierdie kerkverband se geskiedenis. Oor die spesifieke redes is alreeds baie geskryf en word steeds diepgaande gesprekke gevoer en navorsing gedoen. Buiten sterftes (Hanekom 2014) en 'n afname in geboortesyfers (Kleynhans 2013; Oosthuizen 2013) word oor die impak van die emosionele woedereaksie oor die politiek, die verwerping van apartheid, die Belhar-belydenis en liberale teologie steeds debat gevoer.

Oosthuizen (2014) stel dat indien hierdie redes wel gewig dra as die kernoorsake van die krimping in die NG Kerk, die Afrikaanse Protestantse Kerk (APK) drasties sou gegroei het. Dit was egter nie die geval nie. Ook by die ander twee susterskerke, die Hervormde Kerk en die GKSA, word die krimpende tendens konstant waargeneem (Dreyer 2009a; Kleynhans 2013; Oosthuizen 2014; Terblanche 2014). Hanekom (2014) meen die diepste oorsaak van die krimpende krisis is die feit dat gelowiges nie 'n sendinghart het nie. Hendriks (1996:142, 143) bewoord dit anders, maar die bedoeling is grootliks sinoniem, naamlik 'n gebrek aan Godskennis.

Binne die swart GKSA-gemeentes, ontbreek betroubare statistiek grootliks (Van Helden 2015a). Die redes hiervoor is onder andere die behoefte aan leiding in die proses hoe om inligting binne'n gemeente te versamel, administratiewe tekortkomings en geletterdheid. Verder is die lidmaatgetalle van gemeentes, in vergelyking met die enorme bevolkingspotensiaal, teleurstellend. Die oorsaak hiervan kan in dieselfde terme as by die wit gemeentes geformuleer word, naamlik gebrekkige sendingharte en 'n gebrek aan Godskennis. Navorsing onder die swart GKSA-gemeentes toon dat evangelisasie nie gedoen word nie en dat stagnasie meewerk dat gemeentes nie groei nie. Hierdie verskynsels word verdiep deur ongeletterdheid, die geweldige tekort aan bedienaars van die Woord en die enorme aantal permanente vakante gemeentes (vgl. 'Navorsing onder die gemeentes wat die afgelope 10 jaar tot die GKSA toegevoeg is' hieronder). By die wit en swart kerke is daar'n groot mate van ooreenkoms wanneer sendingharte en Godskennis ter sprake is.

As sendingharte en Godskennis in gebreke bly, leef die missie van Christus nie in gelowiges nie. Waar die missie van Christus nie geleef word nie, word die kerk 'n waardelose en irrelevante tydverdryf en 'n saak wat maklik eenkant toe geskuif kan word (Kleynhans 2013; vgl. ook Barna \& Kinnaman 2011). Die een gedeelte van die vraag wat in hierdie artikel na vore kom, kan soos volg geformuleer word: Waar is die gereformeerde lidmate in wit kerke dan?

Oosthuizen (2014) en Kleynhans (2013) stel dat emigrasie van wit gereformeerdes as deel van die weglooplidmate getel kan word, maar ook die lidmate wat na die charismatiese kerke toe oorloop. Hierby is daar duisendes wat om ander redes bloot verdwyn. Hierdie verdwynverskynsel plaas die werklikheid van 'n anderse soort spiritualiteit op die voorgrond. Dit is ' $n$ tendens wat toenemend in die wit gereformeerde kerkverbande waargeneem word (Oosthuizen 2013). Hiervolgens beskou die huidige afwesige oudlidmate hulleself tog steeds as geestelik, maar nie meer as tradisioneel godsdienstig nie (Kleynhans 2013). Hierdie anderse soort spiritualiteit fokus, aldus Loubser (2014:228), op die individu se ervaring en hoe dit in die individu se lewe buite die kerk as instelling uitdrukking vind.

Dreyer (2009a) is van mening dat die tradisionele wit hoofstroomkerke, die plaaslike gemeenskapskerke en die onafhanklike megakerke nie oor die vermoë beskik om hierdie soort buitekerklikheid, anderse spiritualiteit, of selfs ongeloof te keer nie (vgl. ook Barna \& Kinnaman 2011). Buitekerklikheid word tot ' $n$ groot mate bewerkstellig deurdat lidmate uit 'n gemeente vertrek en nie weer by 'n ander gemeente aansluit nie. Sodanige belydende lidmate verdwyn en word nie weer opgespoor sodat redes vir die verdwyning bekom kan word nie. Redes van hierdie groep verdwynende lidmate kan daarom ook nie gedokumenteer word nie. Pavlovitz (2014) voeg sy mening by tot die begrip buitekerklikheid deur sy skrywe op die webwerf van Churchleaders. Daar stel hy dat die buitekerklike mens van vandag bloot net as sondige en gebroke mense leef en so aanvaar moet word; hulle is mense wat wel, ten spyte van hulle afwesigheid in kerke, steeds onhoorbaar roep om 'n liefdevolle uitreik na hulle toe. Deur hierdie uitspraak word die relevansie van die missionale kerk benadruk.

Hierdie individualistiese, anderse godsdienstigheid benadruk die groot verskuiwing wat vanaf die eens tradisionele godsdienstigheid plaasgevind het tot en met vandag waar dit anders geleef en beleef word (Brouwer et al. 2007:183). Sosiologiese navorsing in Kanada, Nieu-Zeeland, Australië, Brittanje en Amerika getuig 'n geruime tyd reeds van hierdie verskuiwing (Hadaway, Kirk \& Penny 2005:307-322; Smietana 2006:85-88; Ward 2004:3). Binne die Afrikaanse tradisionele stroom was die gelowige se godsdienstigheid eens 'n 'diep eksistensiële betrokkenheid' (Du Toit et al. 2002:8-12) wat tot uiting gekom het deur nederige dankbaarheid en erkenning van God se goedheid - 'n godsdienstigheid wat intussen groot verskuiwings ondergaan het.

Die ander gedeelte van dieselfde vraag wat in hierdie artikel hanteer word, fokus op swart kerke en word vanuit 'n ander lewenservaring gestel: Waarom is die swart gereformeerde kerke nie groeiend en tot oorlopens toe vol nie? Is dié wat geëvangeliseer moet word nie juis buitekerklik en anders nie? Dit bring die wit en die swart GKSA-kerke weereens by 'n punt van ooreenstemming, naamlik dat diegene wat buite die kerk is, ongeag die redes daarvoor, in die lig van die missio Dei die erns van 'n missionale bediening beklemtoon.

Omdat die uitbewegende en afwesige oudlidmate vanuit die wit gereformeerde kerke verdwyn het, kan daar nie maklik vasgestel word wat die algemene hedendaagse godsdienstigheid van spesifiek hierdie afwesiges werklik 
is nie. Daar kan ook nie gestel word dat hulle uitgesproke ateïste is nie. Tog kan geargumenteer word dat daar 'n afstand tussen hulle en die steeds krimpende gereformeerde susterskerke is. Die afstand (die wêreld buite teenoor die wêreld binne die kerk) word duidelik deur Kleynhans (2013) en Oosthuizen (2013; 2014) geskets, naamlik dat die individualistiese leefwyse van die hedendaagse mens die kerk grootliks uitsluit.

Ungerer (2013) gebruik woorde soos kwyn, verdwyn en sterwensbegeleiding wanneer hy die dalende tendens in die $\mathrm{NH}$ Kerk bespreek. Ungerer formuleer twee moontlike uitkomste waarnatoe die tendens beweeg. Die eerste is om die huidige werklikheid te besef en daadwerklik aan te pas sodat groei moontlik gemaak kan word, of dat die laertrekmentaliteit gehandhaaf word met die onvermydelike gevolg dat die wit susterskerke stelselmatig verdwyn (vgl. 'Steekproef: Die krimpende tendens van GKSA-gemeentes van 2005-2015'). Laasgenoemde uitkoms sluit die swart tradisionele niegroeiende GKSA-gemeentes in (vgl. 'Navorsing onder die gemeentes wat die afgelope 10 jaar tot die GKSA toegevoeg is' hieronder).

Tog is daar persone soos Wrogeman van Duitsand (Admin 2013) en Niemandt (aangehaal in Loubser 2014:228) van Suid-Afrika wat meen dat die dalende getalle nie 'n moedelose uitwerking op gelowiges moet hê nie. Volgens Wrogeman (Admin 2013) is die kern van kerkwees om God te verheerlik en dat dit God is wat oorlewing beheer en gelowiges daarin lei. Hy stel verder dat indien dankbare aanbidding sigbaar word, dit mense van buite die kerk behoort te lok. Dit is die punt waar buitekerklikes dan weer in die kerk ingenooi moet word. Niemandt (in Loubser 2014) sluit by Wrogeman aan en sê:

die hartklop van die kerk is om mense te help om deel te neem aan die verheerliking van God ... Die kern van die saak gaan oor lidmate se innerlike lewe. Daarom is aanbidding die hartklop van die kerk se lewe. (bl. 228)

Alhoewel Wrogeman en Niemandt se menings op sigself waar is en gewig dra, is die realiteit van dalende getalle in wit gemeentes en die grootskaalse gebrek aan groei in swart gemeentes in die huidige tydvak ' $n$ werklikheid waaraan iets biddend gedoen behoort te word - ten spyte van die wêreldwye tendens van lidmaatafname in hoofstroomkerke (Barna \& Kinnaman 2011). Die oproep tot bekerende omkeer en aanpassings volgens die wil van God weeg tans swaarder as om tot vroom gedagtes soos die van Wrogeman en Niemandt in te stem - gedagtes wat nie daadwerklike dade daarstel om groei in die kerk te bevorder nie (Kleynhans 2013; Van Helden 2013).

\section{Aanpassings in die susterskerke}

Afname in getalle by wit gemeentes, asook uiters min groei in swart gemeentes, raak elke gemeente, maar veral die klein gemeentes. Die beweeglikheid van lidmate in wit gemeentes gaan hand aan hand met 'n afname in gemeentes (Van Helden 2015b). Demografiese verskuiwings as gevolg van beweeglikheid word vergemaklik, omdat keuses in verband met persoonlike vryheid, verskeidenheid en geestelike versorging tans soveel meer is as in die tradisionele verlede. Dreyer (2009a) is van mening dat die dalende tendens in die volgende dekade heel moontlik 'n 'inploffing van lidmaatgetalle' kan laat plaasvind. Saam met die reeds genoemde oorsake rondom die dalende getalle behoort die inploffing momentum te kry, veral wanneer meer lidmate vertrek as wat met 'n bewys van lidmaatskap na 'n ander gemeente oorkom.

Indien vertrekkende lidmate enigsins wel weer by 'n kerk aansluit, word waarskynlik voorkeur aan die groter NG Kerk gegee - 'n waarneming wat die stadiger daling van die NG Kerk in vergelyking met die NH Kerk en GKSA moontlik kan verduidelik (Dreyer 2009a). Die waarneming dat lidmate voorkeur aan die groter NG Kerk gee, is deur 'n GKSA-leraar, ds. Christo van Vuuren, binne sy bediening as geldig bevestig. Die gesprek is op 14 Februarie 2015 gevoer en het gehandel oor GKSA-lidmate wat op veraf preekpunte bedien word. Alhoewel dit enkele gevalle is, verkies sommige van die lidmate om eerder die NG Kerk se dienste by te woon en mettertyd na daardie kerkverband te verskuif.

Hierdie tendens het die verwoording van die tans byna ondenkbare moontlikheid van interkerklike samewerking na vore laat kom. Indien die krimpende tendens in die wit kerke konstant bly, is die moontlikheid van die samesmelting van kerkverbande in die toekoms, hoe vergesog en kompleks ook al, 'n oorweegbare lewensboei. Deur groter eenheid tussen die wit gereformeerde susterskerke (al word dit deur geleidelike krimping bewerkstellig), kan 'n meer eendragtige getuienis immers teenoor die heidenwêreld van Suid-Afrika uitgaan - tot eer van God (Van Helden 2010:448). Hierby kan gestel word dat die tendens van dalende getalle wat as 'n negatief beleef word, tans deur die Gees gebruik word om die oorblywende lidmate tot selfevaluering, 'n ware ondersoek en bekerende omkeer terug na gehoorsaamheid aan die Groot Opdrag te dring (Dreyer 2009b; Venter 2012). Die GKSA se sinodale omkeerbesluit bevestig ook die besef dat daadwerklike aanpassings ter wille van groei in die kerk, die enigste gehoorsame moontlikheid is (Venter 2012; vgl. ook Gilbert 2004).

Swart gemeentes het nog nooit aan die moontlikheid gedink om met ' $n$ ander gereformeerde gemeente of gereformeerde kerkverband soos die Verenigende NG kerk, saam te smelt om uitdagings die hoof te bied nie, aldus 'n gesprek met ds. P. Modise van Kagiso op 3 November 2015. Samewerking vind wel op sinodale vlak en ook sporadies op plaaslike vlak plaas wanneer die gemeenskap bedreig word soos met die opstande oor xenofobia. Die eintlike uitdaging agter die samewerking of samesmelting is die nypende tekort aan leraars, evangeliste en helpers.

Dreyer (2009b) formuleer 'n gemeente wat aan die Groot Opdrag gehoorsaam is as 'n potensieel groeiende gemeente. Hierdie spesifieke gehoorsame groep mense het sekerheid oor waarom hulle as gemeente in daardie spesifieke 
gemeenskap moet wees. Hierdie versekerde gesindheid rig lidmate om aangevuur te bly en laat hulle besef dat introversie (eie instandhouding of 'n laertrekgesindheid) nie die primêre taak van die gemeente bly nie. So 'n gemeente besef hulle deel nie net die evangelie nie, maar ook die harde werklikheid van die omgewing (konteks). Dreyer (2009b) se navorsing bevestig dat 'n gunstiger tendens waargeneem word waar 'n missionale gemeentebouproses ter wille van kerkgroei in werking gestel is (vgl. 'Bevindings na aanleiding van die statistiek (Van Helden 2015b)' en 'Redes waarom groei plaasgevind het ondanks die krimpende tendens').

Die vraag bly egter waar die gereformeerde wit lidmate dan is. Om op demografiese verskuiwings te fokus, bring navorsers by 'n doodloopstraat, aangesien verskuiwings numeries gegee word en geen verdere persoonlike inligtinggewende dokumentasie oor die redes vir die verskuiwings bestaan nie. Tog word gepoog om binne hierdie beperking op die verdwyningsproses van lidmate binne die Afrikaanssprekende steekproefgemeentes van die GKSA te fokus.

Binne die swart GKSA-gemeentes is demografiese verskui wings, dus lidmate wat met 'n attestaat vertrek of wat met 'n attestaat aansluit, 'n uiters rare verskynsel. Volgens die statistiese inskrywings in die Almanak, is evangelisasie nie 'n saak wat getalle opskuif nie, aangesien die kolom vir evangelisasie oorwegend nulle vertoon. Dit dui op stagnasie. Weens stagnasie en die tradisionele manier van dink en doen te midde van 'n oorlewingstryd, is die moontlikheid van samewerking met byvoorbeeld die Verenigende NG Kerk waarskynlik nog nooit bedink nie. Krimpende gemeentes is nie die hoofkrisis by swart GKSA-gemeentes nie, maar wel die tekort aan leraars, evangeliste en helpers om die talle vakante en gestagneerde gemeentes te bedien (Van Helden 2015a).

\section{Steekproef: Die krimpende tendens in GKSA-gemeentes van 2005-2015}

Die werkswyse wat in die steekproef gevolg is, is die volgende: Die Jaarboek (Du Plessis 2014; Vogel et al. 2014) is gebruik om binne elke klassis die grootste en die kleinste gemeentes as respondente te neem, asook 'n gemeente wat in dieselfde klassis in getalle tussen hierdie twee pole lê. Die doel met die steekproef was om vas te stel of die krimpende tendens na 10 jaar afneem of toeneem en wat die belangrikste redes vir die verdwyning van lidmate is. Aangesien die jaarboeke van die GKSA as bronne gebruik is, word die inligting as die naaste aan korrek aanvaar.

In hierdie steekproef is 77 gemeentes binne Suid-Afrika en Namibië betrek. Waar gemeentes saamgesmelt het, word dit as deel van die krimpende tendens beskou en word dit nie verder by die statistiek ingereken nie (Van Helden 2015b). Die volgende sake is nagegaan:

- Krimpende en/of groeiende lidmaatgetalle vanaf die 2005-2009-periode tot 2015 is deur middel van die statistiek in die betrokke Almanakke nagegaan.
- Die mate wat evangelisasie tot die groeiende lidmaatgetalle gedurende die afgelope jaar (2015) bygedra het.

- Die hoeveelheid lidmate wat in 2015 lidmaatskap met die GKSA beëindig het.

- Die hoeveelheid lidmate wat in 2015 sonder attestaat, asook met attestaat, vertrek het.

- 'n Aantal redes waarom getalle gedurende die afgelope dekade, eindigend 2015, in sekere gemeentes nie gedaal het nie.

\section{Bevindings na aanleiding van die statistiek}

Na 10 jaar (2005-2015) is die krimpende tendens binne gemeentes steeds 'n enorme krisisrealiteit (vgl. Van Helden 2013; Van Helden 2015b). Van die 77 steekproefgemeentes, het 7 sodanig gekrimp dat samesmelting met 'n ander gemeente die enigste uitweg was (Witbank, Noordbrug, Van der Bijlpark-Oos, Krugersdorp, Krugersdorp-Oos, Roodepoort en Bloemfontein-Oos). Samesmelting as 'n teken van die krimpende tendens het die gemeentes in Krugersdorp sodanig geraak dat nie een van die oorspronklike gemeentes meer deel van die 2014-2015-navorsing uitgemaak het nie. By die 61 oorblywende steekproefgemeentes het lidmaatgetalle met 5911 oor die afgelope 10 jaar gedaal.

By slegs 9 van die steekproefgemeentes was daar nie 'n daling in die getalle bemerk nie. Die steekproefgemeentes wat die afgelope dekade 'n groeiende lidmaatgetal, hoe gering ook al, getoon het, was Wapadrant (247), Port Elizabeth (39), Kathu (35), Stellenbosch (32), Belville (32), Heilbron (16), Olifantshoek (9), Mariental (5) en Grassy Park (1).

Die belangrikste redes wat hierdie leraars gegee het om groei te verduidelik, was:

- Gehoorsaamheid aan die Groot Opdrag en die seën van die Here daarop.

- Die aanbied van die evangelie op 'n manier wat deur die hedendaagse mens verstaan word.

- Die lidmate wat gasvry, oop en liefdevol teenoor diegene binne en buite die gemeente optree.

- Effektiewe kinderbediening wat plaasvind.

- Werksaanbiedings weens toenemende mynaktiwiteite.

- Werkbiedende stedelike omstandighede.

- Meer lidmate wat in 'n gemeente intrek as wat vertrek.

Evangelisasie as teenvoeter vir die krimpende tendens is tot 'n groot mate nie in die steekproefgemeentes gedoen nie. Evangelisasie wat gedurende 2014 wel gedoen is, het slegs in enkele gemeentes minimaal tot die groei in lidmaatgetalle bygedra. Groei deur evangelisasie weeg nie op teen die getalle wat deur die krimpende tendens geraak word nie. Hieruit word waargeneem dat evangelisasie as deel van die bediening nie 'n hoë prioriteit kry nie, of indien evangelisasie wel gedoen word, dit nie die gewenste resultate oplewer nie. In die steekproefgemeentes is slegs 38 lidmate in 2015 deur evangelisasie tot die GKSA toegevoeg. 
Lidmate wat hulle lidmaatskap beëindig het, belig 'n stille, ernstige en toenemende tendens van verdwynende lidmate. In die steekproefgemeentes het 654 lidmate in een jaar (2014) lidmaatskap beëindig. Die redes hiervoor is onbekend, aangesien die redes van lidmate wat hulle lidmaatskap beëindig, nie noodwendig gedokumenteer word nie. Ungerer (2013) beskryf die tendens as die kerk wat besig is om die lewensasem uit te blaas. Vergelyk ook Gilbert (2004) wat reeds vóór hierdie dekade van die 'slow death' van tradisionele gemeentes gepraat het (vgl. Barna \& Kinnaman 2011), en deur Ungerer (2013) verwoord word as kerke wat besig is met hulle eie 'sterwensbegeleiding'.

Die saak rondom die aanvra of nie aanvra van attestate belig die gelyklopende tendens van aanpassing by 'n anderse godsdienstigheid (Brouwer et al. 2007:183; Kleynhans 2013; Loubser 2014:228), of van die aflegging van godsdiens. Uit die steekproefgemeentes het 583 lidmate binne een jaar (2014) uit die gemeentes vertrek sonder om hulle attestate aan te vra. Dit beteken dat geen getuigskrif oor die spesifieke lidmaat se leer en lewe aan ' $n$ ander gemeente oorhandig kan word nie. Hiervolgens kan die verdwynende 'weglooplidmate' (Oosthuizen 2014) sonder die wete van enige kerkraad by enige ander kerk of kerkverband besoek bring, of permanent uit die kerklike kringe verdwyn. Deur te verdwyn, word die lidmate moontlik deel van die buitekerklike groep waarvan talle hulleself steeds as Christene beskou (Oosthuizen 2013), maar nie meer die kerk besoek nie.

Die teendeel is ook ' $n$ moontlikheid, naamlik dat die weglooplidmate (Oosthuizen 2014) deur hulle individua listiese leefstyl nie meer in die geloof wil volhard nie (Kleynhans 2013), of moontlik nooit gelowig was nie. Hierdie verdwynende lidmate is die groep wat deur die oorblywende lidmate gesoek en geëvangeliseer behoort te word - 'n saak wat volgens die steekproef nie in gemeentes prioriteit dra nie. Die lidmate wat sonder attestate verdwyn, versterk die feit dat daar 'n punt bereik is waar die kerk as ' $n$ instelling beskou word wat nie meer belangrik genoeg geag word om te besoek nie (Oosthuizen 2014; vgl. Barna \& Kinnaman 2011).

Die wat met attestate uit die steekproefgemeentes vertrek het, was 1246. Die aantal lidmate wat met attestate by ander gemeentes binne die steekproefgemeentes aangesluit het, was 1550. Die rondbewegende lidmate wat binne een jaar attestate by ander gemeentes ingedien het, was binne die steekproefgemeentes hoër as diegene wat hulle attestate aangevra het. Beweging na en vanuit klassisse kan breedweg waargeneem word wanneer die attestate wat aangebied word, by gemeentes meer of minder is as die attestate wat vir vertrek aangevra word. Die beweging binne een jaar volgens lidmate wat met attestate vertrek het (1246), en diegene wat sonder attestate vertrek het (583), toon die beweging van 1829 lidmate binne die steekproefgemeentes. In twee-vyfdes van die klassisse (10 van die 25 klassisse) is minder attestate vir lidmaatskap aangebied as waarvoor aansoek gedoen is deur vertrekkende lidmate (Die 26e klassis se gemeentes het saamgesmelt - Wesrand; vgl. Van Helden 2015b).
Volgens die attestate wat binne die steekproefgemeentes ontvang is, kan beweging in die land - ten spyte van die konstante krimpende getalle - soos volg waargeneem word:

- Lidmate beweeg met attestate na die volgende omgewings toe: Die Sentrale Oosrand, Pretoria, Krokodilrivier, Molopo-gebied, Mpumalanga, die verre gebiede van Noordwes, Griekwaland-Wes. Namibië en na die suidelike deel van die land (Karoo-Kei en Boland), terwyl die binneland van hierdie suidelike deel van die land die teenoorgestelde beleef, naamlik ontvolking.

- Lidmate beweeg met attestaat uit die volgende omgewings uit: Limpopo (Waterberg, Soutpansberg), Johannesburg wat die Oos- en Wesrand insluit, asook die Vrystaat en Suid-Natal.

Die totale verlies binne een jaar aan lidmate binne die steekproefgemeentes weens die beëindiging van lidmaatskap (654), asook die lidmate wat nie hulle attestate aangevra het nie en daarom grootliks vir die kerkverband (583) verlore is, beloop 1237 . Dit is $20.93 \%$ van die totale afname binne 10 jaar (5911) binne die steekproefgemeentes. Aan die hand hiervan kan die stilswyende tendens van verdwyning uit die GKSA, die inploffing (Dreyer 2009a), of in die taal van Ungerer (2013) en Gilbert (2004) die slow death, waargeneem word. Dit kan geredelik aanvaar word dat die groep mense deel is van die anderse godsdiensbelewing. Hierdie beweging toon 'n ernstige negatiewe tendens wat die krisis van kerkkrimping beklemtoon en die nood om verdiepende bekering ter wille van kerkgroei belig (Van Helden 2014).

\section{Redes waarom groei plaasgevind het ondanks die krimpende tendens}

Redes wat die afgelope dekade tot groei in die 9 steek proefgemeentes gelei het, is vanaf Januarie tot Maart 2015 nagegaan deur gesprekke met die onderskeie leraars van die betrokke gemeentes te voer. Die gegewens word in die volgende 9 Tabelle aangedui (sien Tabelle 1-9).

In die gesprek wat met een van die leraars van Wapadrand op 14 Februarie 2015 gevoer is, is die volgende redes vir die groei genoem:

Die kerkraad het intensioneel gekies om die bediening te verander en sodanig in te rig om sake wat frustrasie in die GKSA-gemeentes skep, te kanaliseer sodat dit nie die klem in die gemeente kry nie. Een aspek was dat die bediening minder formeel ingerig word. Groot moeite word gedoen om in goeie prediking en gemeentelike belewing te belê. Dit word verder moontlik gemaak deur onder andere 'n verskeidenheid eredienste daar te stel. Daar word gepoog

TABEL 1: Groei met 247 lidmate oor 10 jaar.

\begin{tabular}{lcc}
\hline Gemeente & Jaar & $\boldsymbol{n}$ \\
\hline Wapadrand & 2015 & 1689 \\
& 2008 & 1495 \\
& 2005 & 1442 \\
\hline
\end{tabular}

Bron: Van Helden, S., 2015b, Data van lidmaatgetalle in klassisse met Groot (G)-, Tussen-in (T)- en Klein (K)-gemeentes, Databasis: Kerkgroei Deputate 
om elke groep effektief en op 'n relevante wyse te bedien sodat groei, belewenis en samesyn rondom die Woord en die lied bewerkstellig kan word.

Weens die aanpassings neem die bywoning van die tradisionele diens met orrelbegeleiding af, terwyl die bywoning van die alternatiewe Afrikaanse erediens toeneem. Die atmosfeer is vriendelik, gesindhede is positief, die prediking is relevant en die taalgebruik is verstaanbaar en eenvoudig. Die gemiddelde ouderdom van die gemeente het verskuif en is tans 37 jaar. Dit dui op 'n toename in jonger lidmate wat ook die baie kinders wat gedoop word en die hoë belangstelling in 'n goeie kinderbediening verduidelik.

Die omgewing is gevestig. Ouers wat hierdie omgewing verkies, vind 'n kerk waar die voorskoolse en skoolgaande kinders belangrik geag word, en waar hulle goed en op relevante wyse bedien word. Die taalgebruik in die kinderbediening is verstaanbaar en eenvoudig en die kinders word aangemoedig om hulle maats saam te bring.

Beweging in en uit albei hierdie gemeentes (Kathu en Olifantshoek) vind ook gereeld plaas. In 'n gesprek op 18 Maart 2015 het die leraar gestel dat mynaktiwiteite in en om Kathu deels die beweging veroorsaak. 'n Verdere saak wat tot die getallegroei bydra, is die bediening aan buitekerklike persone. Buitekerklike persone wat eens lidmate van ander kerke was, word bearbei en die aksie werp geleidelik vrug af. Dit word ook sigbaar in die styging van die lidmaatgetalle.

In 'n gesprek met die leraar op 21 Februarie 2015 is gestel dat die aanvanklike inbeweeg na Port Elizabeth se gemeente as 'n werk- en kunssentrum sedert 2007 'n plato bereik het en sedertdien relatief konstant bly.

In die gesprek met die leraar van Bellville wat op 19 Maart 2015 plaasgevind het, is gestel dat die geleidelike toename in

TABEL 2: Groei met 35 lidmate oor 10 jaar.

\begin{tabular}{lcc}
\hline Gemeente & Jaar & $\boldsymbol{n}$ \\
\hline Kathu & 2015 & 232 \\
& 2008 & 178 \\
& 2005 & 197 \\
\hline
\end{tabular}

Bron: Van Helden, S., 2015b, Data van lidmaatgetalle in klassisse met Groot (G)-, Tussen-in (T)- en Klein (K)-gemeentes, Databasis: Kerkgroei Deputate

TABEL 3: Groei met 9 lidmate oor 10 jaar.

\begin{tabular}{lll}
\hline Gemeente & Jaar & $\boldsymbol{n}$ \\
\hline Olifantshoek & 2015 & 81 \\
& 2008 & 82 \\
& 2005 & 72 \\
\hline
\end{tabular}

Bron: Van Helden, S., 2015b, Data van lidmaatgetalle in klassisse met Groot (G)-, Tussen-in (T)- en Klein (K)-gemeentes, Databasis: Kerkgroei Deputate

TABEL 4: Groei met 39 lidmate oor 10 jaar.

\begin{tabular}{lll}
\hline Gemeente & Jaar & $\boldsymbol{n}$ \\
\hline Port Elizabeth & 2015 & 408 \\
& 2008 & 397 \\
& 2005 & 369 \\
\hline
\end{tabular}

Bron: Van Helden, S., 2015b, Data van lidmaatgetalle in klassisse met Groot (G)-, Tussen-in (T)- en Klein (K)-gemeentes, Databasis: Kerkgroei Deputate getalle meestal lidmate is wat met attestasie van ander gemeentes oorgekom het. Dit wil voorkom asof die beweging na die suide van die land grootliks vanaf die noorde van die land geskied. Bydraend hiertoe is dat 'n groot aantal dooplidmate in die afgelope jaar gedoop is. Wat ook positief op die opbou van die gemeente inwerk, is kerkplanting wat besig is om in Rondebosch plaas te vind.

In'n gesprek op 18 Maart 2015 met die leraar van Stellenbosch is genoem dat waar studente betrokke is, wisselende getalle altyd 'n rol speel. Ten spyte van die onsekerheid rondom studentegetalle, word sterk klem op die onderlinge verhoudings en gebede gelê, asook die blootstelling aan dit wat buite die gemeente ' $n$ realiteit is. Moeite word gedoen met die eredienste en veral die aanddienste word meer informeel aangebied. Om koinonia in die gemeente te beklemtoon, word geleenthede geskep om lidmate wat van elders kom, gou tuis te laat voel. Deur kampe, kleingroepe en die algemene vriendelike aanpak in die gemeente, word die bou van verhoudings bevorder.

Die grafiek van groei in die gemeente in Heilbron het teen 2007 'n hoogtepunt beleef en daarna ietwat afgeplat, alhoewel daar in die geheel beskou, 'n mate van groei oor die afgelope 10 jaar was. Tydens 'n gesprek met die leraar op 18 Maart 2015, is gestel dat alhoewel die 2015-Almanak van minimale groei oor die afgelope 10 jaar spreek, die getalle egter drasties aan die groei is. Die 2016-Almanak getuig van die gebeure in die gemeente (140 belydende lidmate). Die enigste rede wat vir groei in die gemeente gegee is, is dat die leraar, die

TABEL 5: Groei met 32 lidmate oor 10 jaar.

\begin{tabular}{lcc}
\hline Gemeente & Jaar & $\boldsymbol{n}$ \\
\hline Belville & 2015 & 439 \\
& 2008 & 437 \\
& 2005 & 417 \\
\hline
\end{tabular}

Bron: Van Helden, S., 2015b, Data van lidmaatgetalle in klassisse met Groot (G)-, Tussen-in (T)- en Klein (K)-gemeentes, Databasis: Kerkgroei Deputate

TABEL 6: Groei met 32 lidmate oor 10 jaar.

\begin{tabular}{lcc}
\hline Gemeente & Jaar & $\boldsymbol{n}$ \\
\hline Stellenbosch & 2015 & 266 \\
& 2008 & 224 \\
& 2005 & 234 \\
\hline
\end{tabular}

Bron: Van Helden, S., 2015b, Data van lidmaatgetalle in klassisse met Groot (G)-, Tussen-in (T)- en Klein (K)-gemeentes, Databasis: Kerkgroei Deputate

TABEL 7: Groei met 16 lidmate oor 10 jaar.

\begin{tabular}{lll}
\hline Gemeente & Jaar & $\boldsymbol{n}$ \\
\hline Heilbron & 2015 & 118 \\
& 2008 & 128 \\
\hline & 2005 & 102 \\
\hline
\end{tabular}

Bron: Van Helden, S., 2015b, Data van lidmaatgetalle in klassisse met Groot (G)-, Tussen-in (T)-en Klein (K)-gemeentes, Databasis: Kerkgroei Deputate

TABEL 8: Groei met 5 lidmate oor 10 jaar.

\begin{tabular}{lll}
\hline Gemeente & Jaar & $\boldsymbol{n}$ \\
\hline Mariental & 2015 & 65 \\
& 2008 & 53 \\
& 2005 & 60 \\
\hline
\end{tabular}

Bron: Van Helden, S., 2015b, Data van lidmaatgetalle in klassisse met Groot (G)-, Tussen-in (T)- en Klein (K)-gemeentes, Databasis: Kerkgroei Deputate 
TABEL 9: Groei met 1 lidmaat oor 10 jaar.

\begin{tabular}{lll}
\hline Gemeente & Jaar & $\boldsymbol{n}$ \\
\hline Grassy Park & 2015 & 113 \\
& 2008 & 113 \\
& 2005 & 112 \\
\hline
\end{tabular}

Bron: Van Helden, S., 2015b, Data van lidmaatgetalle in klassisse met Groot (G)-, Tussen-in (T)-en Klein (K)-gemeentes, Databasis: Kerkgroei Deputate

kerkraad en die gemeente één doel voor oë het en dit is om aan die sendingopdrag gehoorsaam te wees. 'n Projek is ongeveer 10 jaar gelede begin met die doel om sendingwerk finansieel moontlik te maak. Die gemeente het by die besluit gehou en die Here se seën word op alle terreine oorvloedig beleef. Kerkplanting en die ingebruikneming van die nuutgeplante gemeente se fasiliteite het onlangs plaasgevind. Albei gemeentes se kerkrade en gemeentelede het reeds baie tyd saam spandeer en alhoewel daar steeds baie uitdagings is, is die bediening positief en word groei beleef. Die kerkplanting bewerkstellig 'n kragtige momentum in die gemeente.

'n Aantal buitekerklike lidmate uit ander gemeentes het deur hierdie positiewe bediening ' $n$ tuiste in die gemeente gevind. Volgens die nuwe lidmate is die gemeente gasvry, die eredienste is vriendelik, liefde en erkenning word ervaar, die kerk is stabiel en pastorale hulp is beskikbaar. Hiermee saam is daar 'n positiewe bediening met die oog op die groter gemeenskap. Die lidmate en die leraar het besluit om daadwerklik aan te pas om liefde sigbaar en toeganklik te maak vir diegene buite die gemeente. Hierdie besluit het prioriteit geword. Die na-binne-leef van die gemeente is met 'n na-buite-leef vervang. Die opbou van die gemeente en die uitbou funksioneer as 'n onverdeelbare eenheid. Groot genade word beleef - veral ook in tye wanneer hindernisse oorkom moet word.

Getalle het oor die afgelope 10 jaar relatief konstant in Mariental gebly. Na aanleiding van 'n gesprek met die leraar op 14 Februarie 2015 is die styging en daling van getalle te wyte aan die normale beweging van lidmate in en uit die gemeente.

Omstandighede in die gemeente van Grassy Park is uniek en uitdagend. Die afgelope 10 jaar was daar nie groei of krimping nie. Die gemeente beleef heelwat sterfgevalle, maar aangesien hulle deurentyd met evangelisasie besig is, word nuwe lidmate weer toegevoeg. Die jong lidmate vorm 'n bemoedigende fondasie in die gemeente. Hierby is daar ook baie beweging in en uit die gemeente. Die hoofrede is hoofsaaklik armoede wat tot gevolg het dat daar nie lank op 'n plek gebly word nie. Dit word verder bemoeilik deur bende-oorloë, gevare, swak vervoer en ver afstande. Om dit te probeer ondervang, is onlangs met verskillende preekpunte begin en 'n gefokusde toerusting van die lidmate word in die vooruitsig gestel om die bedieningsnood te verlig (Fleischman 2015).

\section{Navorsing onder die gemeentes wat die afgelope 10 jaar tot die GKSA toegevoeg is}

Aangesien die swart GKSA-gemeentes die afgelope 10 jaar deel van die GKSA geword het, is statistiek aangaande hierdie gemeentes uiters beperk en onvolledig. Die gevolgtrekking waarop die navorsing dui, is derhalwe slegs volgens die statistiek wat wel beskikbaar is - statistiek wat nie op onbetwisbare juistheid kan aanspraak maak nie, maar wel tendense sterk aandui (Van Helden 2015a).

Die aantal gemeentes wat deel van die GKSA geword het, is 112. Vakante gemeentes is 52, terwyl 60 gemeentes wel 'n leraar het. Sommige gemeentes word deur dieselfde leraar bedien, aangesien daar slegs 44 leraars in die bediening vir swart GKSA-gemeentes is. Om die probleem rondom die GKSA-statistiek te oorkom, is die 44 leraars tussen 6 September en 1 Oktober 2015 telefonies gekontak om hulle deelname aan die navorsing te verkry. Nadat die vraelyste aan hulle gestuur is, het slegs 9 respondente dit terugbesorg. Van hierdie 9 dokumente was slegs 7 bruikbaar (Van Helden 2015a).

Die klein persentasie respondente wat terugvoer gegee het, is in sekere verskynsels grootliks dieselfde. Die verskynsels kan moontlik as penstrepe van die groter werklikheid binne die swart GKSA-gemeentes dien.

Waar 'n gemeente ' $n$ eie predikant het en nood soos armoede of ongeletterdheid binne die gemeente ervaar word, word geen samewerking met ' $n$ naburige gereformeerde gemeente bedink om verligting van die gemeente se spesifieke nood te bewerkstellig nie. Wat wel sporadies plaasvind, is dat daar onderling tussen die verskillende kerke in 'n spesifieke gebied saamgewerk word wanneer die groter gemeenskap bedreig word (vgl. 'Aanpassings in die susterskerke'). Elke gemeente worstel alleen voort in hulle eie stryd om oorlewing.

In die Almanak is die statistiese gegewens in verband met evangelisasie as 'n moontlikheid om lidmate tot die gemeente toe te voeg, onbetroubaar en ongeloofwaaardig, aangesien nulle meesal in daardie kolom voorkom. Indien daar jaar na jaar geen groei deur evangelisasie plaasvind nie, kom die roeping van die kerk met reg onder verdenking. Aangesien dit jaar na jaar dieselfde bly, kan dit 'n sterk aanduiding van intense stagnasie wees tesame met redes soos ongeletterdheid, onbetrokkenheid, administratiewe onvermoë, en dies meer.

Die drietal verskynsels, naamlik dat lidmaatskap beëindig word, dat met attestaat vertrek word of dat lidmate uit 'n ander gemeente tot die gemeente toegevoeg word, is rare verskynsels. In die lig van die feit dat toevoeging deur evangelisasie nie plaasvind nie, bevestig hierdie drietal verskynsels die handhawing van die status quo.

Die tendens wat deur die terugvoer van slegs $22 \%$ van die leraars waargeneem word, getuig van 'n baie intense toestand van stagnasie en nood wat in die swart GKSA-gemeentes heers. Ten spyte van die duisende beskikbare mense rondom die gemeentes, vind groei nie plaas nie. Waar wel gearbei word, word dit soms deur ongeletterdheid en die nypende tekort aan leraars en helpers gerem. Die gestagneerde toestand, te midde van die enorme armoede in Suid-Afrika, 
kan jong manlike lidmate beswaarlik motiveer om hulleself as leraars te bekwaam.

\section{Groeiende swart gemeentes}

Alhoewel groei in die swart GKSA-gemeentes nie die heersende tendens is nie, het ds. Phungula van die Reformed Family Worship Church in Kwa Zulu-Natal, wel van sy gemeente se 'wenstrategie' melding gemaak. In sy bediening van 20 jaar staan die getalle op 395 lidmate (belydende- en dooplidmate). In die e-pos wat hy op 10 November 2015 gestuur het, som ds. Phungula (2015) die groeistrategie soos volg op (vertaalde weergawe):

(1) Wanneer 'n nuwe area besoek word, word 'n tent vir ongeveer twee weke daar opgeslaan. In die tydperk word die kerk aan belangstellendes bekend gestel, klasse word begin en dit lei tot geloofsbelydenis en doop (as die persoon nie as baba gedoop is nie). ' $n$ Leraar om die nuwelinge te bedien, word dan benodig. (2) 'n Een-dag 'open air Gospel campaign' word in 'n besige gebied gereël. Daar word gesing, gepreek, boekies uitgedeel en almal word uitgenooi na die Sondag-erediens. (3) 'n 'Internal revival-program' word vir ongeveer twee dae gereël met die doel om die vuur by lidmate aan te blaas en om mense buite die gemeente daarnatoe uit te nooi. (4) Selgroepe vergader een maal per week waartydens Bybel gelees en gebid word, onderlinge samesyn word geniet en leierskap word geïdentifiseer.

Die uitkomste is om geestelike groei en groei in getalle te bewerkstellig. Die uitdagings in die gemeente is die geweldige tekort aan leraars/evangeliste, die behoefte aan persone om die leraar op 'n daaglikse basis in die bediening by te staan, asook die behoefte aan die onderrig en opleiding van leiers op verskillende vlakke (verskillende strukture vir teologiese opleiding en indiensopleiding).

Ds. Semenya van Diepsloot stel in sy e-pos van 9 November 2015, dat hierdie preekpunt, wat 'n wyk van die Randburggemeente is, volhoubare groei toon. Groei in die Diepslootwyk kan aan die volgende toegeskryf word (vertaalde weergawe):

\begin{abstract}
die ondersteuning deur die ander wit wyke in die gemeente om in wat ook al nodig is vir die bediening, te voorsien; dat 'n visie en missie vasgestel is en dat juis dít rigting gee in die bediening; dat Project Andrew (Johannes 1:35-42) uit die visie en missie voortgevloei het - sodanig dat op aktiewe wyse 'n netwerk, aan die hand van die Bybel, daargestel en volgehou word; dat lidmate geleer en behou word deur die I.C.A.S.-metode, wat neerkom op onderrig en opleiding, samesyn, aanbidding en diens; en dat lidmate aangevuur word deur aktiewe diensgroepe, konferensies, kampe en Bybelstudies.
\end{abstract}

\section{Twee vrae, een antwoord}

Dit is duidelik dat geweldige nood by wit én swart gemeentes bestaan. Alhoewel die een groep vra waar die lidmate heen is, vra die ander groep waar is die lidmate wat in die gemeente behoort te wees. Alhoewel die vrae verskil is die antwoord en die oplossing vir wit en swart GKSA-gemeentes dieselfde, naamlik 'n lewende missionale bediening. Om dit moontlik te maak, behoort die verskillende groepe se uitdagings duidelik verstaanbaar voor die deure van wit en swart leraars gestel te word. Dit is duidelik dat die verskillende tale, agtergronde, kulture, omstandighede soos geletterdheid en ongeletterdheid, armoede en welvaart, tekort aan geleenthede en opleiding, tekort aan leraars en evangeliste, asook die krisisse van krimping en stagnasie deur die een enkele punt van ooreenkoms oorspan word, naamlik denkverandering gerig op missio Dei (Van Helden 2010:461-469; Van Wyk 2014:1-9).

Deur hierdie ooreenkoms te erken, sou eenheid in broederskap makliker beleef kan word. Die verskillende uitdagings van wit en swart gemeentes behoort dan aanvullend, saam én ter wille van mekaar aangepak te word (Van Helden 2015a). 'n Bekeerde bewussyn is sprekend van Christusgesentreerde denke en behoort in dade sigbaar te word. Opregte afsmeking ten opsigte van die nood, behoort in wedersydse gebede ook gehoor te word. Gefokusde dade kan 'n eensgesinde, moedige en gelowige kerkverband laat posvat - 'n kerkverband wat die hand aan die ploeg slaan, maar tog aanhou omkyk na wat agter is, is nie vir die koninkryk van God geskik nie (vgl. Luk 9:62).

\section{Gevolgtrekking}

In verband met die tendens van die krimpende lidmaattal in die Afrikaanse susterskerke, is aan die hand van die steekproef in die GKSA aangetoon dat lidmaatgetalle steeds afneem. Die belangrikste waarnemings rondom die GKSAsteekproefgemeentes is dat gemeentes deur samesmelting verdwyn, dat evangelisasie grootliks in die gemeentes afwesig is, dat daar groot getalle lidmate is wat lidmaatskap met die wit GKSA beëindig, asook lidmate wat sonder attestaat vertrek. Die lidmate wat met attestaat vertrek en dit wel by ander gemeentes aanbied, belig die huidige beweging van lidmate binne die GKSA. Die verdwynende lidmate bevestig die stille inploffing van die kerkverband wat 'n kommerwekkende realiteit vir die volgende dekade daarstel. Toenemende afname van lidmaatgetalle kan daartoe lei dat kerkverbande die moontlikheid van samewerking, ter wille van gereformeerde oorlewing, oorweeg. Die redes wat vir groei gegee is, is die volgende:

- Die algehele omkeer op alle terreine om gehoorsaam te wees aan die Groot Opdrag. Dit sluit kerkplanting in en die positiewe uitwerking wat dit op 'n gemeente het. Dit behels ook evangeliebediening aan buitekerklikes, asook die bediening aan die gemeente om verhoudings op alle vlakke te bou.

- Werksgeleenthede soos by myne en by die kus, asook die beweging vanuit die noorde van die land na die suidelike dele.

- Die uit- en inbeweeg van lidmate wat relatief konstant is.

In verband met die swart lidmaatgetalle van die GKSAgemeentes, is dit duidelik dat alhoewel die statistiese gegewens grootliks onvoldoende en twyfelagtig is, dit duidelik blyk dat gemeentes nie groei nie, dat evangelisasie nie plaasvind nie en dat die beweging uit en in gemeentes ' $n$ rariteit is. 'n Gemeente wat wel groei, het doelbewus uit die 
toestand van stagnasie opgestaan en 'n eie unieke Bybelse strategie binne hulle konteks daargestel. Groei in gemeentes word ernstig deur die tekort aan leraars, geld, opleiding, geletterdheid, asook beweeglikheid gerem. Met hierdie uitdagings behoort nie op 'n gestagneerde wyse mee vrede gemaak te word nie. Dit behoort spoedeisend en ernstig hanteer te word.

Die wêrelde van wit en swart gemeentes lyk skynbaar ligjare verwyderd te wees. Tog, wanneer die oplossing, naamlik 'n lewende missionale bediening aanvaar word, is eenheid reeds grootliks bedink. Deur die liefdesgebod kan hande gevat word, kreatiewe oplossings bedink word en die hand kan aan die ploeg geslaan word om na 'n verbeterende kerkpraktyk te beweeg.

'n Sterk riglyn om kerkgroei te bevorder, is om gemeentebou as 'n praktiese en gunstige tendens sigbaar te laat word om sodoende die voorheen introverte, krimpende geneigdheid tot 'n groeiende missionale gemeente om te keer. Dit is 'n bemoedigende en uitvoerbare rigtingwyser wat in die verloop van die volgende dekade nuwe geleenthede vir gemeentes daar kan stel. Deur van die tendense bewus te word, kan die susterskerke se leraars, kerkrade en gemeentelede gehoorsaam omkeer en in gebedsafhanklikheid missionaal beplan. Bekerende verandering in die GKSAgemeentes, deur wit en swart, sal nie weggesteek kan word nie. Dit sal deel van 'n groeiende missionale tendens kan uitmaak - 'n tendens wat deur die Gees gedrewe, 'n lig in 'n donker land kan laat verrys, tot eer van God.

\section{Erkenning \\ Mededingende belange}

Die outeur verklaar dat sy geen finansiële of persoonlike verbintenis het met enige party wat haar nadelig kon beïnloed het in die skryf van hierdie artikel nie.

\section{Literatuurverwysings}

Admin, 2013, Getalle, gemeentes en gebed, besigtig op 8 Januarie 2015, vanaf http://192.185.30.195/ kerkbode/getalle-gemeentes-en-gebed/

Barna, G. \& Kinnaman, D., 2011, Five trends among the unchurched, besigtig op 26 Oktober 2015, vanaf https://www.barna.org/barna-update/culture/685-fivetrends-among-the-unchurched\#.Vi-98yvlZVd

Brouwer, R., De Groot, K., De Roest, H., Sengers, E. \& Stoppels, S. (reds.), 2007, Levend liggaam: Dynamiek van christelijke geloofsgemeenschappen in Nederland, Kok, Kampen.

Dreyer, W., 2009a, Die kleiner kerk en gemeente, besigtig op 12 Januarie 2015, vanaf http://www.google.co.za/url?sa=t\&rct=j\&q=\&esrc=s\&source=web\&cd=16\&ved= OCDgQFjAFOAo\&url=http $\% 3 \mathrm{~A} \% 2 \mathrm{~F} \% 2 \mathrm{Fwww}$.gemeentes.co.za $\% 2$ Fdokumente $\% 2$ Fkruisgewys $\% 2$ Fklein gemeentes $\% 2$ FNHKA $\% 2520$ Klein $\% 2520$ Kerk. doc\&ei=Ib2wVPehDMf-Us_agMAK\&usg=AFQjCNEe1Zs21c4dAEmjeZy5k5bD_687 doc\&ei=lb2wVPehDMf-Us_agMAK\&usg
CQ\&sig2=mQ366Dsu1puoeigM8IKWvQ
Dreyer, W., 2009b, Hoofstuk 5: Bevinding, besigtig op 12 Januarie 2015, vanaf http:// upetd.up.ac.za/thesis/available/etd-10232010-183047/unrestricted/04chapter5. pdf

Du Plessis, W., 2014, e-pos, 7 Oktober, wymiedup@gksa.co.za

Du Toit, F., Hofmeyr, H., Strauss, P., Van der Merwe, J., 2002, Moeisame pad na vernuwing: Die NG Kerk se pad van isolasie en die soeke na 'n nuwe relevansie, Barnabas, Bloemfontein.

Fleischman, J., 2015, e-pos, 14 Oktober, johan@flansa.co.za

Gilbert, D.E., 2004, “"Deep change" or "slow death"? A practical road guide for the highway of change: A learning manual for church boards', PhD thesis, Faculty of Theology, Western Theological Seminary, Michigan.

Hadaway, C., Kirk, M. \& Penny, L., 2005, 'How many Americans attend worship each week? An alternative approach to measurement', Journal for the Scientific Study of Religion 44(3 Suppl), 307-322.

Hanekom, B., 2014, Getalle, gemeentes en gebed, besigtig op 8 Januarie 2015, vanaf http://192.185.30.195/ kerkbode/getalle-gemeentes-en-gebed/

Hendriks, H.J., 1996, 'Kerkspieël en die NGK statistiek in die wyer perspektief van die Suid-Afrikaanse bevolkingsensusse 1911-1991', Nederduitse Gereformeerde Teologiese Tydskrif 37(1), 138-145.

Kleynhans, S., 2013, Insiggewende artikel van ons moderator oor krimpende gemeentes!, besigtig op 10 Januarie 2015, vanaf http://ngverwoerdpark.org.za/ profile/SteynKleynhans

Loubser, G.M., 2014, Die verskeidenheid in spiritualiteit: 'n Transdissiplinêre benadering, besigtig op 10 Januarie 2014, vanaf http://ngtt.journals.ac.za/pub/ article/viewFile/523/543

Oosthuizen, J., 2013, 'Krimpende kerke nie sleg nie', Kerkbode 190(1).

Oosthuizen, J., 2014, Krisis kom vir leë kerke, besigtig op 8 Januarie 2015, vanaf http:// www.ngvishoek.co.za/index.php?option=com_content\&view=article\&id $=1255 \%$ 3Akrisis-kom-vir-lee-kerke\&Itemid $=105$

Pavlovitz, J., 2014, Dear church, here's why people are REALLY leaving you, viewed 12 January 2015, from http://www.churchleaders.com/outreach-missions/outreachmissions-articles/244545-dear-church-heres-people-really-leaving.html/3

Phungula, S., 2015, e-pos, 10 November, phungulasz@gmail.com

SA, see South Africa.

Semenya, K., 2015, e-pos, 11 November, kwena@gkrandburg.org.za

Smietana, B., 2006, 'Statistical illusion: New study confirms that we go to church much less than we say', Christianity Today 50(4), 85-88.

South Africa, Department of Statistics, 2015, Mid-year population estimates, viewed 17 November 2015, from http://www.statssa.gov.za/publications/P0302/ P03022015.pdf

Terblanche, E., 2014, Afvalligheid onder Afrikaners het ' $n$ werklikheid geword, besigtig op 9 Januarie 2015, vanaf http://apk.co.za/index.php/laaikas/kommentaar/83kommentaar-blog/28-februarie-2014/afvalligheid-onder-afrikaners/496afvalligheid-onder-afrikaners

Ungerer, A., 2013, Hoe lyk die kerk in ons wêreld?, besigtig op 12 Januarie 2015, vanaf http://www.hervormer.co.za/images/Mei\%202013.pdf

Van Helden, P., 2013, 'Denke as krisisterrein in die verskynsel van kerkkrimping by tradisioneel Afrikaanssprekende susterkerke', Verbum et Ecclesia 34(1), 1-12. http://dx.doi.org/10.4102/ve.v34i1.677

Van Helden, S., 2010, "n Hermeneuties-empiriese strategie rakende die verskynsel van kerkkrimping in tradisioneel Afrikaanse "susterkerke" in Suid-Afrika - 'n Prakties-teologiese studie', PhD-proefskrif, Fakulteit Teologie, Noordwes Universiteit, Potchefstroom

Van Helden, S., 2014, 'Aspekte van 'n omkeerproses', In die Skriflig 48(1), 1-13. http:// dx.doi.org/10.4102/ids.v48i1.1696

Van Helden, S., 2015a, Report on research conducted on the tradition of collecting information as projected in the statistics in the annual GKSA-Almanak, as well as research conducted on the RCSA churchgrowth ministries and turnaround, Data base: Churchgrowth Deputies.

Van Helden, S., 2015b, Data van lidmaatgetalle in klassisse met Groot (G)-, Tussen-in $(T)$ - en Klein (K)-gemeentes, Databasis: Kerkgroei Deputate.

Van Wyk, G., 2014, 'Missionale kerk, missio Dei en kerkverband: 'n Diskussie', In die Skriflig 48(1), 1-9.

Venter, P., 2012, e-pos, 27 Februarie, dspietventer@oosdoppers.co.za

Vogel, W., Van Schaik, J., Letebele, M.J., Erasmus, M.C., Fourie, J. \& Du Plessis, W., 2014, Die Almanak van die Gereformeerde Kerke in Suid-Afrika vir die jaar 2015, Jg 141, V \& R Drukkery, Pretoria.

Ward, K., 2004, 'Is New Zealand's future churchless?' Stimulus 12(2), 2-12. 